\title{
Distinct arbuscular mycorrhizal fungal communities associate with different manioc landraces and Amazonian soils
}

\author{
Clara P. Peña-Venegas ${ }^{1,2} \cdot$ Thomas W. Kuyper $^{3} \cdot$ John Davison $^{4} \cdot$ Teele Jairus $^{4} \cdot$ Martti Vasar $^{4} \cdot$ Tjeerd Jan Stomph $^{1}$. \\ Paul C. Struik ${ }^{1}$ - Maarja Öpik ${ }^{4}$
}

Received: 23 October 2018 / Accepted: 25 March 2019 /Published online: 26 April 2019

(C) The Author(s) 2019

\begin{abstract}
Manioc (Manihot esculenta Crantz) is an important tropical crop that depends on arbuscular mycorrhizal (AM) association for its nutrition. However, little is known about the richness and species composition of AM fungal communities associating with manioc and possible differences across soils and manioc landraces. We studied the diversity and composition of AM fungal communities present in the roots of different manioc landraces and surrounding soils in indigenous shifting cultivation fields on different Amazonian soil types. A total of 126 AM fungal virtual taxa (VT; phylogenetically defined taxonomic units) were recovered from soil and root samples using 454 sequencing of AM fungal SSU rRNA gene amplicons. Different AM fungal communities occurred in different soil types. Minor differences occurred in the composition of AM fungal community associating with different manioc landraces, but AM fungal richness was not different among them. There was a low similarity between the AM fungal communities colonizing manioc roots and those recorded in the soil, independently of differences in soil properties or the manioc landrace evaluated. Rhizophagus manihotis and Glomus VT126 were the most abundant AM fungal species colonizing manioc roots. Contrasting with the results of earlier spore-based investigations, all the AM fungi identified as indicator species of particular manioc landraces were morphologically unknown Glomus species. In conclusion, different manioc landraces growing in common conditions associated with distinct AM fungal communities, whereby AM fungal communities in soils did not necessarily reflect the AM fungal communities colonizing manioc roots.
\end{abstract}

Keywords Amazon region $\cdot$ Arbuscular mycorrhizal fungal virtual taxa $\cdot$ Cassava $\cdot$ Manihot esculenta $\cdot$ Shifting agriculture

Electronic supplementary material The online version of this article (https://doi.org/10.1007/s00572-019-00891-5) contains supplementary material, which is available to authorized users.

Clara P. Peña-Venegas

cpena@sinchi.org.co

1 Centre for Crop Systems Analysis, Wageningen University \& Research, Droevendaalsesteeg 1, 6708 PB Wageningen, The Netherlands

2 Instituto Amazónico de Investigaciones Científicas Sinchi, Avenida Vásquez Cobo entre Calle 15 y 16, Leticia, Amazonas, Colombia

3 Soil Biology Group, Wageningen University \& Research, Droevendaalsesteeg 3, 6708 PB Wageningen, The Netherlands

4 Department of Botany, University of Tartu, 40 Lai St, 51005 Tartu, Estonia

\section{Introduction}

Manioc (Manihot esculenta Crantz; Euphorbiaceae), also known as cassava, is native to the Amazon region and is an important staple crop throughout the tropics. It is also emerging as an important crop for bio-fuel production and other industrial processes (Aristizábal et al. 2007; FAO 2000). Manioc is widely cultivated by subsistence farmers with limited access to inputs in marginal acidic low-fertility soils (ElSharkawy and Tafour 2010). However, while manioc is productive on low-fertility soils, it produces higher yields in fertile or fertilized soils (Cadavid et al. 1998; El-Sharkawy 2004; Omorusi and Ayanru 2011). Therefore, it is likely that much subsistence cultivation of manioc fails to realize the full yield potential of the crop. Arbuscular mycorrhiza (AM) may represent a low-cost resource that could improve plant nutrient acquisition and enhance manioc production (Cardoso and Kuyper 2006). 
Manioc is a highly mycotrophic species (Habte and Byappanahalli 1994), establishing arbuscular mycorrhizal associations when AM fungi are present. Many studies have demonstrated the positive effect of AM on manioc performance in comparison with non-mycorrhizal treatments (Ceballos et al. 2013; Dodd et al. 1990; Fagbola et al. 1998; Sieverding 1990; Sieverding and Howeler 1985; Sieverding and Toro 1990). AM association in manioc has been studied by assessing AM colonization of manioc roots, and by characterizing soil AM fungal communities co-occurring with manioc, in the hope of identifying suitable AM fungal symbionts for manioc (Séry et al. 2016; Straker et al. 2010; Voko et al. 2013). The latter approach has mainly relied on descriptions of AM fungal spores isolated from soil or trap cultures, as until recently, limited methods were available for studying AM fungi actively involved in the symbiosis (i.e., within plant root tissues) (Anderson and Cairney 2004; Öpik et al. 2006). Based on descriptions of AM fungal spores co-occurring with manioc, Rhizophagus irregularis (Ceballos et al. 2013), Paraglomus occultum (Dodd et al. 1990), Acaulospora colombiana, and Ambispora appendiculata (Séry et al. 2016) have been reported as commonly encountered symbionts for manioc.

Molecular analysis of AM fungal communities in soils or root samples is becoming commonplace. This approach has indicated that the composition of AM fungal communities colonizing plant roots does not necessarily mirror that of the AM fungal communities found in the surrounding soil (Saks et al. 2014; Varela-Cervero et al. 2015). Additionally, plant roots are usually colonized by multiple AM fungus species; e.g., Öpik et al. (2006) reported between 4 and 24 different AM fungal taxa (virtual taxa (VT), which are phylogenetically defined taxonomic units). It is therefore questionable how well the earlier lists of AM fungal species isolated from soils shared with manioc characterize the AM fungi colonizing manioc roots.

A recent molecular analysis provided a first insight into the AM fungi colonizing manioc roots (Herrmann et al. 2016). That study showed that manioc roots cultivated in a commercial system in Thailand hosted diverse AM fungal communities with 50-58 VT of AM fungi per manioc field and 8 to 38 VT per manioc root sample. It also indicated that the AM fungal taxon Glomus VT403 showed a strong affinity for manioc.

However, commercial production of manioc is not the most common production system in the tropics. Manioc is generally cultivated under low-input/low-output production systems, particularly when it is cultivated as a food crop (Leihner 2002). Although intensive cultivation has been promoted for manioc in recent years, shifting cultivation, in which manioc is cultivated in small fields intercropped with other crops, is still one of the most common production systems used for manioc production worldwide (Delaquis et al. 2018; Fresco
1986; Leihner 2002). In subsistence farming systems, it is common for small farmers to cultivate many local manioc landraces in their fields (Cavechia et al. 2014; Emperaire and Peroni 2007; Nakabonge et al. 2017; Peña-Venegas et al. 2014), including bitter and sweet manioc landraces, which contain different levels of root cyanogenic compounds (Burns et al. 2010; McKey et al. 2010). The way manioc is grown as a staple crop in low-input production systems under shifting cultivation will create a different soil environment for AM fungal communities in comparison with high-input production system soils under continuous cultivation. Therefore, the insight from Herrmann et al.'s report (2016) might not apply to more diverse subsistence manioc cultivation systems.

Here, we studied the AM fungal communities associated with manioc in indigenous swidden plots (shifting cultivation fields) in the Colombian Amazon. We used molecular approaches to characterize the diversity and composition of AM fungal communities colonizing manioc roots and those occurring in surrounding soils. In doing so, we also aimed to distinguish the AM fungal communities associating with different manioc landraces, since this might provide a better indication of suitable symbiotic partners than previous spore-dependent approaches. Indigenous swidden plots were visited to collect samples of soils and manioc roots to study AM fungal communities in the two types of samples using rDNA amplicon sequencing to identify the VT present.

\section{Materials and methods}

\section{Study area and manioc cropping systems}

This study includes samples from two locations in the Colombian Amazon region: the Middle Caquetá River region and the municipality of Leticia (Fig. 1). The Middle Caquetá River region is located between $00^{\circ} 22^{\prime} 14.9^{\prime \prime} \mathrm{S}$ and $00^{\circ} 55^{\prime}$ $11^{\prime \prime} \mathrm{S}$, and $72^{\circ} 06^{\prime} 36.3^{\prime \prime} \mathrm{W}$ and $71^{\circ} 26^{\prime} 18.3^{\prime \prime} \mathrm{W}$. The elevation of this region ranges between 200 and $300 \mathrm{~m}$ above sea level, with slopes ranging from 7 to $25 \%$. Average annual rainfall is $3000 \mathrm{~mm}$ (Duivenvoorden and Lips 1993), with lowest precipitation between December and February. The region is located at the intersection of sedimentary plains of Tertiary origin (dissected terraces and hills), with rocky outcrops of Paleozoic origin, creating elevated plateaus. The Caquetá River and its tributaries cross the area, generating alluvial plains. The dominant vegetation is a mosaic of mature and secondary tropical forest of different ages, combined with indigenous swidden agricultural plots near indigenous settlements.

The municipality of Leticia is approximately $450 \mathrm{~km}$ south of the Middle Caquetá River region. The municipality of Leticia is located between $04^{\circ} 05^{\prime} 29.5^{\prime \prime} \mathrm{S}$ and $04^{\circ} 10^{\prime} 09^{\prime \prime}$ 


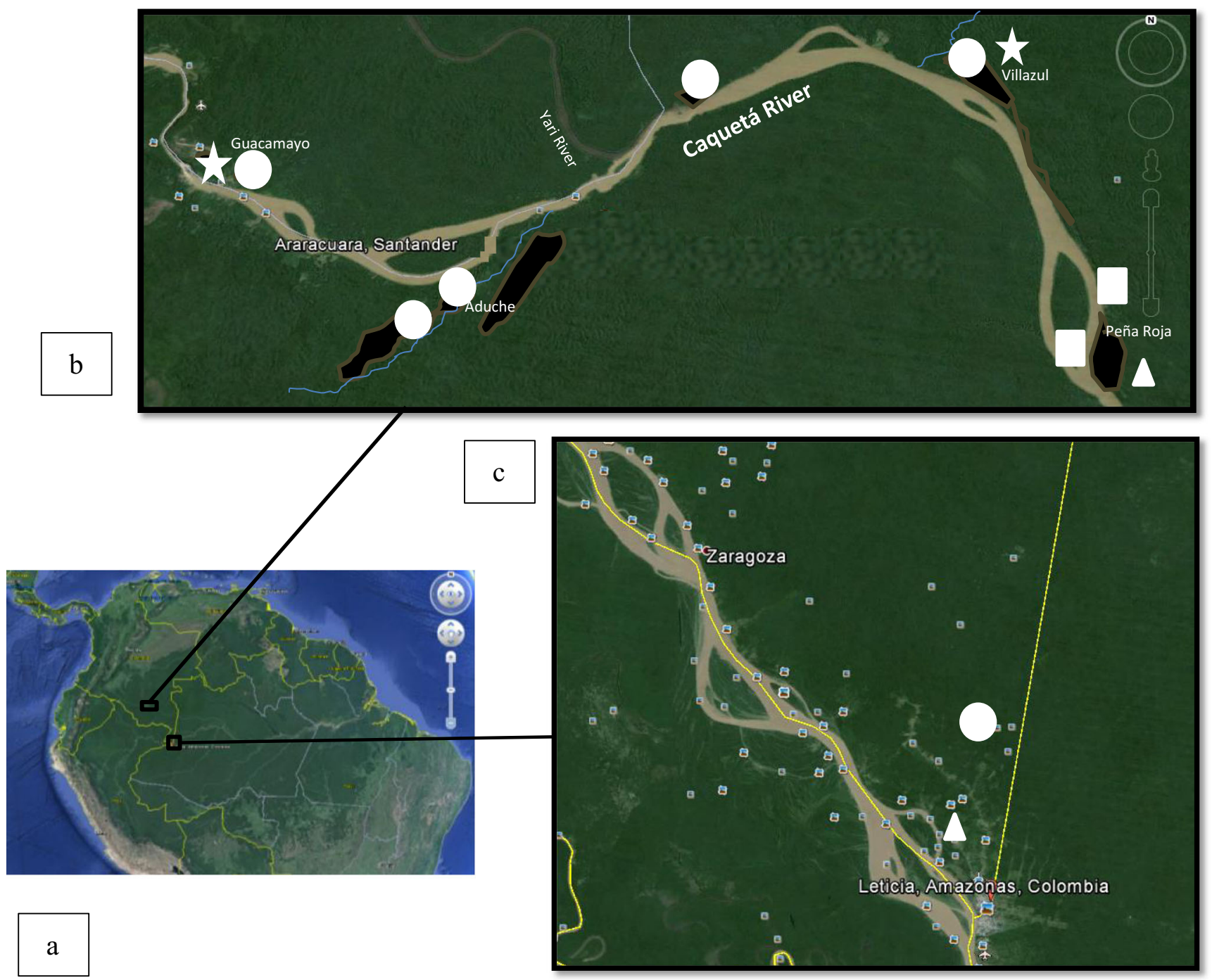

Fig. 1 Study area in the Colombian Amazon region (A) used for the collection of root and soil samples for the study of AM fungal communities: (B) middle Caquetá River region and (C) the municipality of Leticia. Triangles correspond to swiddens located on Ferralsols; stars correspond to swiddens located on Podzols; circles correspond to swiddens located on Anthrosols; squares correspond to swiddens located on Fluvisols. Images obtained from the program Google Earth (2014)
$\mathrm{S}$, and $69^{\circ} 29^{\prime} 55.6^{\prime \prime} \mathrm{W}$ and $70^{\circ} 00^{\prime} 28.9^{\prime \prime} \mathrm{W}$. The area is characterized by flat plains of ancient, low alluvial terraces with shallow soils. The elevation of this area is around $100 \mathrm{~m}$ above sea level with slopes between 1 and $3 \%$. Average annual rainfall is $2800 \mathrm{~mm}$, with a similar seasonal pattern of rainfall as in the Middle Caquetá region. The area is covered by mature tropical forest with abundant epiphytes (IGAC 1979) and moderate human influence, secondary forests, and indigenous swidden agricultural plots near indigenous settlements.

In both areas, smallholders cultivate manioc in traditional shifting cultivation systems intercropped with other plant species. Details of fields and the cropping systems used for manioc cultivation can be consulted in Table A1 of the Online Resource. Generally, in swidden plots on uplands with
Ferralsols, Podzols, or Anthrosols (WRB soil classification 2016), small distinct patches of sweet and bitter landraces were cultivated within fields, but in some cases, sweet and bitter landraces were planted intermixed. The pattern observed by McKey and Beckerman (1993) of sweet manioc landraces planted at the center of swiddens and bitter maniocs at the edges was not observed. In floodplains characterized by Fluvisols (WRB soil classification), sweet manioc landraces are most widely cultivated in the swidden fields, but bitter manioc landraces and other crops were always present.

A total of 12 fields were visited to collect soil and manioc root samples: two swiddens on Ferralsols (one in each location), two on Podzols at the Middle Caquetá River region, six swiddens on Anthrosols (five in the Middle Caquetá River region and one in the municipality of Leticia), and two 
swiddens on Fluvisols in the Middle Caquetá River region (Table A1 Online Resource). Root and soil sampling was carried out in 2013 during January and February in the municipality of Leticia, and during April, May, and August in the Middle Caquetá region.

\section{Characterizing manioc landraces}

In swidden fields, an inventory and classification of landraces as sweet and bitter maniocs were made with local farmers. As some manioc landraces were collected in more than one community, a morphotypic characterization of all manioc landraces cultivated locally in the communities was made based on morphological indices developed by CIAT (CIAT 1984) to assess which landraces were common and which ones differed among communities.

To ensure that plants collected from the same landrace were genotypically similar and distinguishable from plants of other landraces, a sample of apical sprouts was collected in paper bags with silica gel for subsequent molecular analysis. At the Manioc Genetics Laboratory of CIAT, Palmira (Colombia), samples were lyophilized overnight using an Alpha 2-4 LD plus Martin Christ Freeze-dryer (Germany). From lyophilized samples, DNA was extracted using Qiagen (Venlo, Netherlands) DNeasy Plant 96-well extraction kits. To characterize manioc landraces, 93 single nucleotide polymorphisms (SNPs) previously tested by the team of the Manioc Genetics Laboratory of CIAT were used. Samples were processed using the protocol for SNP genotyping with the EP1 $1^{\mathrm{TM}}$ system and SNP type assays of Fluidigm ${ }^{\circledR}$ version S.01 following instructions from the manufacturer ( $\mathrm{Li}$ et al. 2010). Allele-specific PCR was performed as described by PeñaVenegas et al. (2014). Data sets obtained were analyzed using the Fluidigm SNP Genotyping Analysis software (Spurgeon et al. 2008).

A subset of manioc root samples of five different manioc landraces was selected for molecular analysis.

\section{Root sampling}

Manioc roots were collected from plants that farmers were harvesting. We did not have direct control over the manioc landraces harvested, as manioc selection for harvesting was dependent on the farmers' decisions. At the time of root collection, the local name of each manioc landrace was recorded. In each swidden field, samples of manioc roots of different manioc landraces were collected. From each plant, between 5 and 25 fine roots were collected from the bulky roots (from the uppermost $20 \mathrm{~cm}$ depth; corresponding to the depth in which the roots were growing) or the stem roots of each harvested plant. The length of fine roots collected from each plant ranged between approximately 3 and $10 \mathrm{~cm}$. From all the manioc root samples collected, we selected 31 samples from five manioc landraces (Table A2 of the Online Resource) that were cultivated in different soils. Root samples were stored at $-70{ }^{\circ} \mathrm{C}$ for further molecular analyses.

\section{Soil sampling}

In parallel with manioc root collection, a sample of approximately $100 \mathrm{~g}$ of the soil adhering to roots and from the hole where each manioc plant had been growing was collected for AM fungal community analysis. Additionally, a pooled soil sample of about $500 \mathrm{~g}$ from each field $(0-10 \mathrm{~cm}$ depth) was collected for physicochemical analysis. Soil samples were placed in polyethylene bags and transported in iceboxes to the laboratory for further processing. Soil samples were then dried at room temperature $\left(25{ }^{\circ} \mathrm{C}\right.$ and $50 \%$ humidity) and stored at $4{ }^{\circ} \mathrm{C}$ for further soil physicochemical analysis or at $-70{ }^{\circ} \mathrm{C}$ for further molecular analysis.

\section{Soil physicochemical analysis}

The following analyses of soil physicochemical properties were conducted according to the standardized methodologies of the National Soil Laboratory (IGAC 2006): soil texture (granulometry); $\mathrm{pH}$ (1:1 in water); percentage of organic carbon (Walkley-Black); cation exchange capacity expressed in centimole per kilogram (with $1 \mathrm{~N}$ ammonium acetate at $\mathrm{pH}=$ 7); $\mathrm{Ca}, \mathrm{Mg}, \mathrm{K}$, and $\mathrm{Na}$ expressed in milligram per kilogram (by DTPA extraction); percentage of total bases (with $1 \mathrm{~N}$ ammonium acetate at $\mathrm{pH}=7$ ); and available phosphorus expressed as milligram per kilogram of dry soil (Bray II).

\section{DNA-based identification of AM fungi}

Soil DNA was isolated from $5 \mathrm{~g}$ of dry soil sample using the PowerMax ${ }^{\circledR}$ Soil DNA Isolation Kit (MoBio Laboratories, Inc.), with modifications described by Gazol et al. (2016). For root DNA isolation, $70 \mathrm{mg}$ of dry roots were crushed in tubes with $1.1 \mathrm{~mm}$ and $2.3 \mathrm{~mm}$ tungsten carbide beads in a mixer mill at 30 rotations per second. The samples were shaken three times for $2 \mathrm{~min}$, each time moving the position of the tubes to ensure complete crushing of the roots. Root DNA was isolated using the PowerSoil ${ }^{\circledR}$ DNA Isolation kit (MoBio Laboratories, Inc.) with modifications to the manufacturer's instructions, as described in Saks et al. (2014).

Glomeromycotina (Spatafora et al. 2016) sequences were amplified from soil and root DNA extracts using the nuclear SSU rRNA gene primers NS31 and AML2 (Lee et al. 2008; Simon et al. 1992), linked to sequencing primers A and B, respectively (Öpik et al. 2013). For sequence identification of the different soil and root samples, barcodes of 8 bp long were designed and used (Parameswaran et al. 2007).

Two-step PCR was used as in Öpik et al. (2013). In the first PCR reaction, PCR primers were linked to barcodes and 
Fig. 2 a Venn diagram showing the number of arbuscular mycorrhizal fungal virtual taxa (VT) recovered from manioc root samples (upper red circle), soil samples (lower green circle), and in both (overlap). b Rarefaction (taxon accumulation) curves of root samples (upper black line) and soil samples (lower red line)
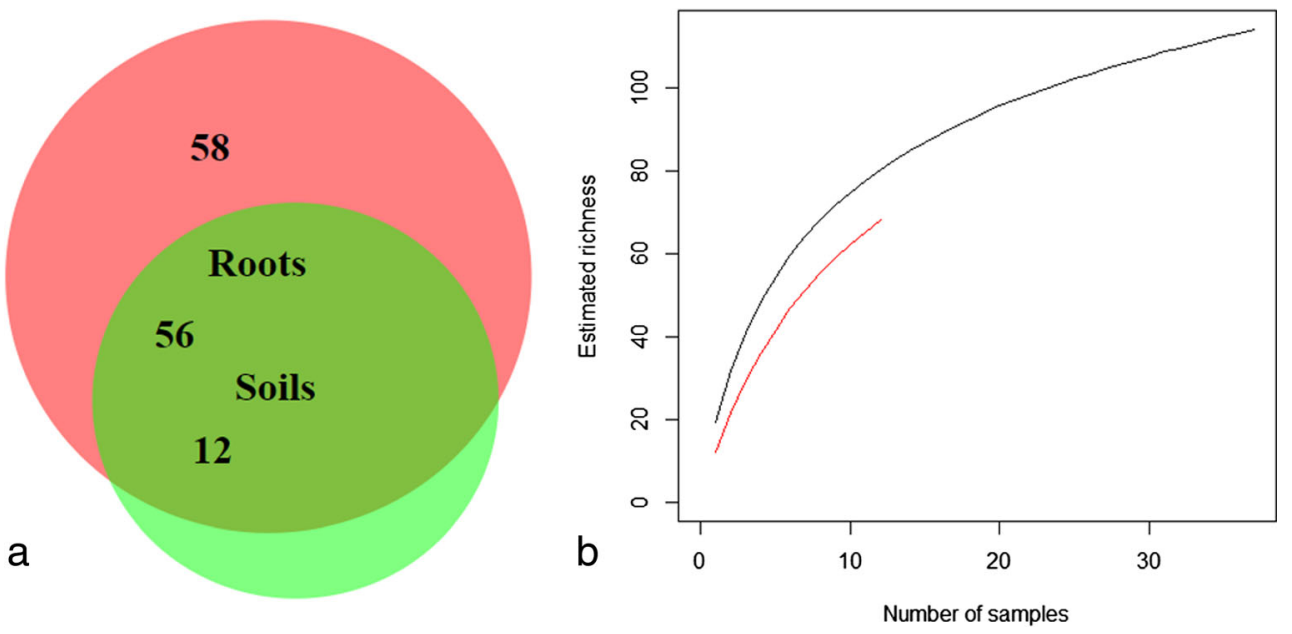

partial 454 sequencing adaptors A and B. The composite forward primer for this PCR reaction was 5'GTCT CCGACTCAG (NNNNNNNN) TTGGAGGGCAAGTC TGGTGCC 3', and the reverse primer 5' $5^{\prime}$ TGG CAGTCTCAG (NNNNNNNN) GAACCCAAACACTT TGGTTTCC $3^{\prime}$, where the $\mathrm{A}$ and $\mathrm{B}$ adaptors are underlined, the barcode is indicated by Ns in parentheses, and primers NS31 and AML2 are shown in italics. The PCR was run under the following conditions: $95^{\circ} \mathrm{C} \times 15 \mathrm{~min}$ followed by $35 \mathrm{cy}-$ cles of $94{ }^{\circ} \mathrm{C} \times 30 \mathrm{~s}, 58{ }^{\circ} \mathrm{C} \times 30 \mathrm{~s}$, and $72{ }^{\circ} \mathrm{C} \times 1 \mathrm{~min}$, and finalizing $72{ }^{\circ} \mathrm{C} \times 10 \mathrm{~min}, 10^{\circ} \mathrm{C}$ hold and end. In the second step, the full $\mathrm{A}$ and $\mathrm{B}$ adaptors were used as PCR primers, obtaining the full 454-adaptor + barcode + PCR primer construct. In the second PCR, the product of the first PCR was diluted $10 \times$ and used as template. For the second PCR, complete 454-adaptors A (5'CCATCTCATCCCTGCGTGTC TCCGACTCAG 3') and B (5' CCTATCCCCTGTGT GCCTTGGCAGTCTCAG 3') were used as primers.

The reaction mix contained $5 \mu 1$ of Smart-Taq Hot Red $2 \times$ PCR Mix $\left(0.1 \mathrm{U} \mu \mathrm{l}^{-1}\right.$ of Smart Tag Hot Red Thermostable DNA Polymerase, $4 \mathrm{mM} \mathrm{MgCl} 2,0.4 \mathrm{mM}$ each of dNTPs; Naxo OÜ, Estonia), $0.2 \mu \mathrm{M}$ each primer, and $1 \mu \mathrm{l}$ of template DNA, in a total volume of $10 \mu \mathrm{l}$. The reactions were run on a
Thermal cycler 2720 (Applied Biosystems, Foster City, CA, USA) following the conditions reported by Davison et al. (2012). PCR products were separated by electrophoresis in a $1.5 \%$ agarose gel in $0.5 \mathrm{TBE}$. The PCR products were extracted from the gel using the Qiagen QIAquick Gel Extraction kit (Qiagen GmbH, Germany) and purified with Agencourt ${ }^{\circledR}$ AMPureXP® PCR purification system (Agencourt Bioscience, Beverly, MA, USA). From the obtained DNA mix, $1.7 \mu \mathrm{g}$ was sequenced on a Genome Sequencer FLX System, using Titanium Series reagents (Roche Applied Science, Mannheim, Germany) at GATC Biotech AG (Konstanz, Germany). Preparation of barcoded PCRs and PCR product purification for 454 sequencing was performed by BiotaP LLC (Tallinn, Estonia). The sentence "From the obtained DNA...." has been modified. Please check if the modification is correct and retained the intended meaning of the sentence.

\section{Bioinformatics and phylogenetic analyses}

Reads from 454 sequencing that carried the correct barcode and forward primer (NS31) were used for further bioinformatics analyses. Individual sequences (amplicons) with an

Table 1 Physicochemical composition of swidden soils from where soil and manioc root samples were collected to study arbuscular mycorrhizal fungal communities. Values are means and standard deviations given in parentheses

\begin{tabular}{llllllllllll}
\hline SOIL & Sand & Clay & $\mathrm{pH}$ & $\mathrm{OC}$ & $\mathrm{CEC}$ & $\mathrm{Ca}$ & $\mathrm{Mg}$ & $\mathrm{K}$ & $\mathrm{Na}$ & $\mathrm{P}$ \\
\hline Ferralsol $n=2$ & $54.0(5.7)$ & $19.0(7.1)$ & $4.4(0.3)$ & $2.7(0.3)$ & $14.4(3.2)$ & $1.4(0.5)$ & $0.7(0.4)$ & $0.4(0.2)$ & $0.1(0.1)$ & $36.0(34.6)$ \\
Podzol $n=2$ & $84.0(1.4)$ & $11.5(2.1)$ & $3.5(0.4)$ & $5.8(6.8)$ & $22.2(24.0)$ & $0.1(0.0)$ & $0.1(0.0)$ & $0.2(0.1)$ & $0.0(0.0)$ & $0.4(0.5)$ \\
Anthrosol $n=6$ & $81.4(12.7)$ & $8.0(5.5)$ & $4.2(0.5)$ & $2.4(1.8)$ & $9.7(4.8)$ & $2.3(4.2)$ & $0.4(0.5)$ & $0.2(0.2)$ & $0.1(0.0)$ & $220.4(279.4)$ \\
Fluvisol $n=2$ & $32.5(10.6)$ & $19.0(1.4)$ & $4.3(0.3)$ & $1.4(0.4)$ & $12.1(0.6)$ & $2.4(2.3)$ & $1.6(1.5)$ & $0.2(0.0)$ & $0.1(0.0)$ & $9.1(12.8)$ \\
$p$ value & 0.06 & 0.08 & 0.29 & 0.69 & 0.22 & 0.21 & 0.29 & 0.37 & 0.32 & 0.06 & 3.13 \\
Chi-square & 7.45 & 6.52 & 3.76 & 1.46 & 4.43 & 4.42 & 3.74 & 3.13 & 3.35 \\
\hline
\end{tabular}


Table 2 Arbuscular mycorrhizal fungal virtual taxa (VT) richness in different soil types

\begin{tabular}{lllll}
\hline Soil type & $\begin{array}{l}\text { Number of } \\
\text { samples }\end{array}$ & $\begin{array}{l}\text { VT from soil } \\
\text { samples }\end{array}$ & $\begin{array}{l}\text { VT from root } \\
\text { samples }\end{array}$ & $\begin{array}{l}\text { Total VT per } \\
\text { soil type }\end{array}$ \\
\hline Ferralsol & $(n=2)$ & 26 & 32 & 47 \\
Podzol & $(n=2)$ & 36 & 65 & 77 \\
Anthrosol & $(n=6)$ & 44 & 82 & 91 \\
Fluvisol & $(n=2)$ & 12 & & 76 \\
$p$ value & & 0.42 & & 82 \\
Chi-square & & 2.83 & & \\
\hline
\end{tabular}

average quality score $\geq 25$ and length of $\geq 170$ bp (excluding the barcode and primer) were selected. Sequences longer than 520 bp were trimmed to that length. Chimeric sequences were detected and removed using UCHIME v7.0.1090 (Edgar et al. 2011) in the reference database mode, using the default parameters and MaarjAM database (status February 2015, 5264 sequences, 348 VT). The MaarjAM database contains representative sequences covering the NS31/AML2 amplicon from published environmental Glomeromycotina sequence groups and morphologically described taxa, classified into so-called virtual taxa (VT) (Öpik et al. 2009, 2014), and morphologically described taxa. The percentage of possible chimeras was $0.2 \%$ of cleaned sequences. The remaining reads were identified against Glomeromycotina in the Maarj $A M$ database with BLAST+ v2.5.0 (Camacho et al. 2009) using an open reference operational taxonomic unit picking approach (Bik et al. 2012). The criteria used to discriminate between a match and a no-match were a sequence similarity $\geq 97 \%$; an alignment length not differing from the length of the shorter of the query (454 reads), and reference (MaarjAM database) sequences by more than 5\%; and a BLAST $e$ value of $<1 \mathrm{e}-50$. Those sequences that did not match any VT in the MaarjAM database were compared against the International Nucleotide Sequence Database Collaboration (INSDC) with lowered thresholds using similarity $\geq 90 \%$, an alignment length at least $90 \%$ of the shorter of the query, and an alignment length not differing from the shorter of the query and subject sequences by more than $10 \%$.
In order to identify sequences that could represent new $\mathrm{VT}$, sequences receiving no match against MaarjAM but a match against Glomeromycotina in the INSDC were clustered at 99\% similarity level using BLASTclust (BLAST v2.2.26) (Altschul et al. 1990). Up to four sequences from each of the resulting clusters (excluding singleton clusters) were aligned with all sequences available in the MaarjAM database using the MAFFT multiple sequence alignment web service in JALVIEW version 2.8 (Waterhouse et al. 2009) and subjected to a neighbor-joining phylogenetic analysis in TOPALi v2.5 (Milne et al. 2004). Novel VT were identified on the basis of sequence similarity and tree topology with AM fungal genus and species on the phylogeny of all Glomeromycotina VT (Öpik et al. 2013).

Sequences of each VT and site combination were submitted to the EMBL database under accession numbers LT797839-LT798819. Filtering, removal of primer and barcode sequences from reads, and parsing of BLAST output were carried out at the Department of Botany, University of Tartu, Tartu, using a series of Python and Java programs developed by Davison et al. (2012).

SNPs derived from manioc plants were read, organized, and analyzed to describe the plant population genetic structure. Genetic structure was estimated using a Bayesian model approach (Kawuki et al. 2013) with the STRUCTURE 2.2 software (Pritchard et al. 2000). This Bayesian analysis determines the minimum number of populations $(\mathrm{K})$ that may generate the observed diversity based on the rate of change in the $\log$ probability of the data between successive $K$ values. After obtaining the $K$ value, each sample is compared with each one
Table 3 Arbuscular mycorrhizal fungal virtual taxa (VT) richness in the roots of different manioc landraces cultivated in indigenous swidden fields of the Amazon region of Colombia. Means and standard deviations given in parentheses. Differences between landraces were not statistically significant (Kruskal-Wallis chisquare $=4.65 ; p=0.34$ )

\begin{tabular}{|c|c|c|c|c|c|}
\hline \multirow[t]{3}{*}{ Soil type of swidden fields } & \multicolumn{5}{|l|}{ Manioc landrace } \\
\hline & \multirow{2}{*}{$\begin{array}{l}\text { Sweet landrace } \\
\text { Cáscara morada }\end{array}$} & \multicolumn{4}{|c|}{ Bitter landraces } \\
\hline & & Amarilla & Borugo & Guava & Yucuna \\
\hline Ferralsols & 8 & 31 & & & \\
\hline Podzols & & & 31 & 46 & 21 \\
\hline Anthrosols & 20 & 24 & 37 & 42 & 57 \\
\hline Fluvisols & 47 & 39 & 55 & 63 & 65 \\
\hline Mean (SD) & $25(20)$ & $31(7)$ & $41(12)$ & $50(11)$ & $48(23)$ \\
\hline
\end{tabular}


Fig. 3 Non-metric multidimensional scaling twodimensional analysis (NMDS) to visualize the variation of $\mathrm{AM}$ fungal communities among four soil types: A (Anthrosols) in blue color, Fe (Ferralsols) in red color, $\mathrm{Fl}$ (Fluvisols) in green color, and $\mathrm{P}$ (Podzols) in black color.

Ellipses indicate one standard deviation around the centroid position of each soil type

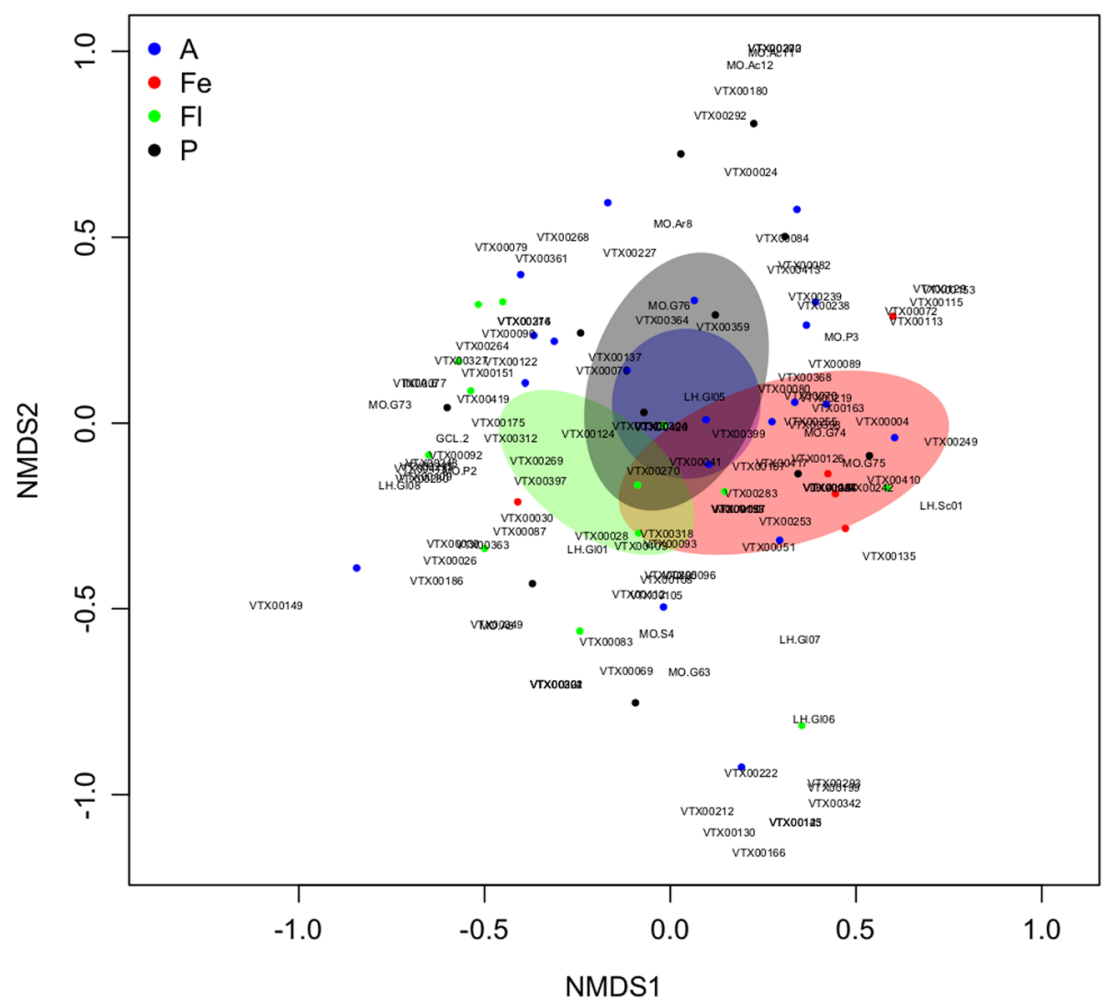

Statistics

of the $K$ populations to discriminate samples into groups. STRUCTURE outputs were processed using CLUMPP v1.1.2 (Jakobsson and Rosenberg 2007) to determine the best alignment.

The completeness of AM fungal sampling among soil and root samples was assessed using rarefaction (function rarefy from the
Fig. 4 Non-metric multidimensional scaling twodimensional analysis (NMDS) to visualize the variation of AM fungal communities colonizing the roots of five different manioc landraces: A (Amarilla) in blue color, B (Borugo) in red color, C (Cáscara morada) in black color, $\mathrm{G}($ Guava) in green color, and Y (Yucuna) in pink color. Ellipses indicate one standard deviation around the centroid position of each type of manioc landrace

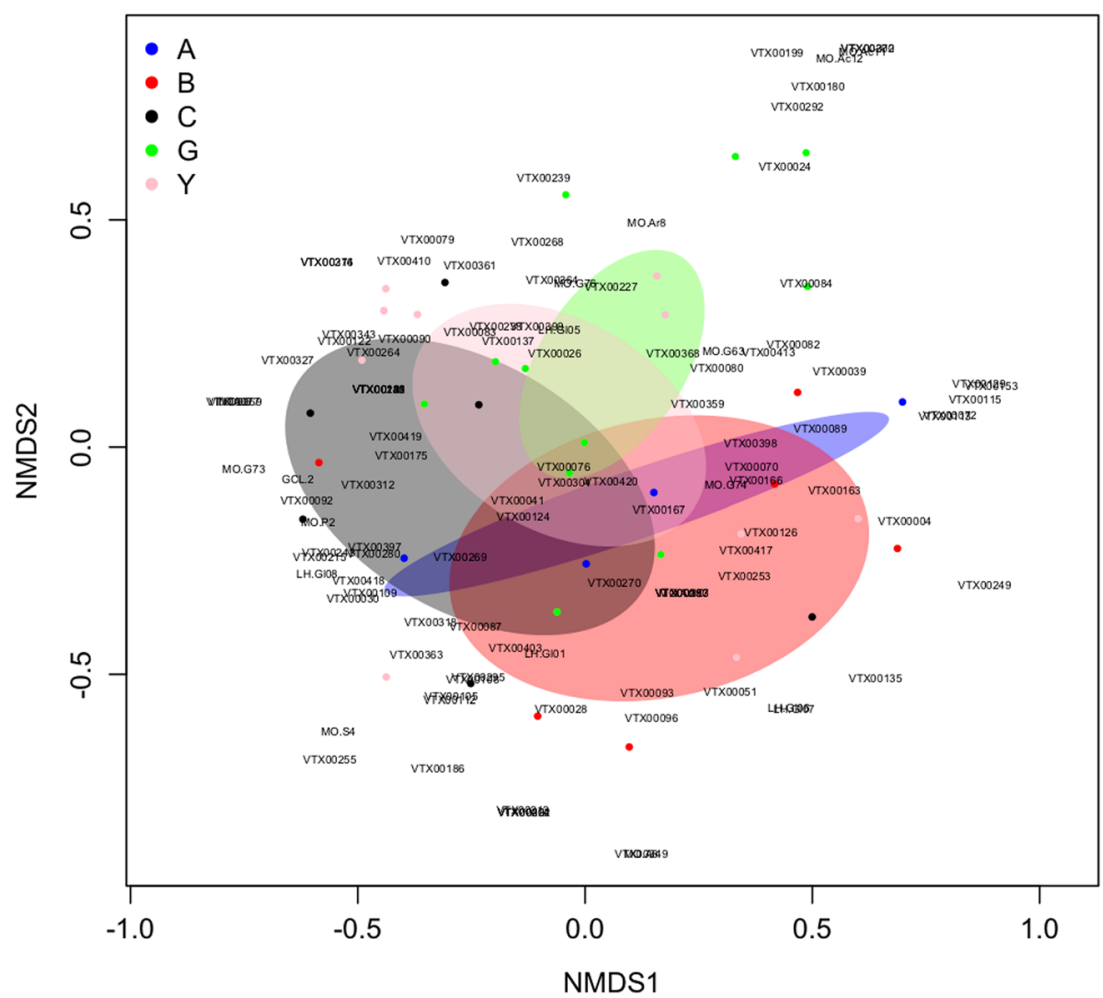




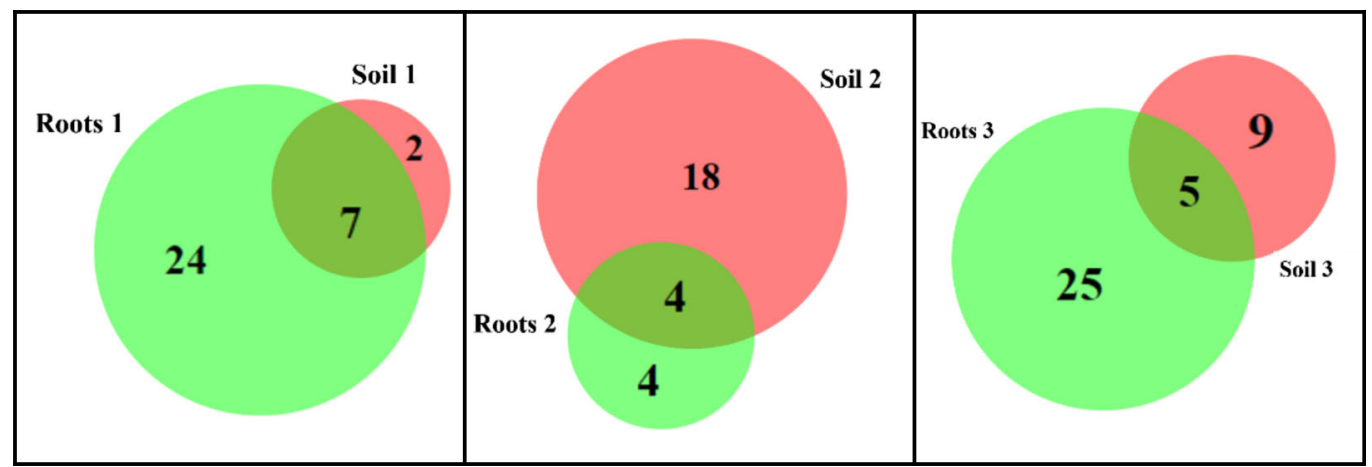

Field 1

Field 2

Field 3

No. plants sampled $=2 \quad$ No. plants sampled $=1 \quad$ No. plants sampled $=2$

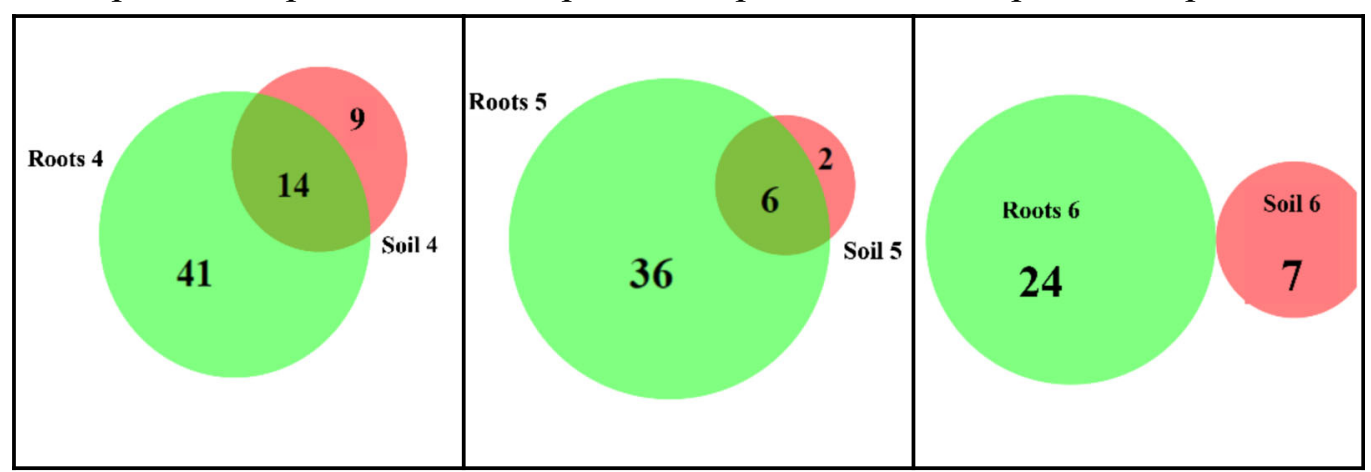

Field 4

Field 5

Field 6

No. plants sampled $=7 \quad$ No. plants sampled $=3 \quad$ No. plants sampled $=2$

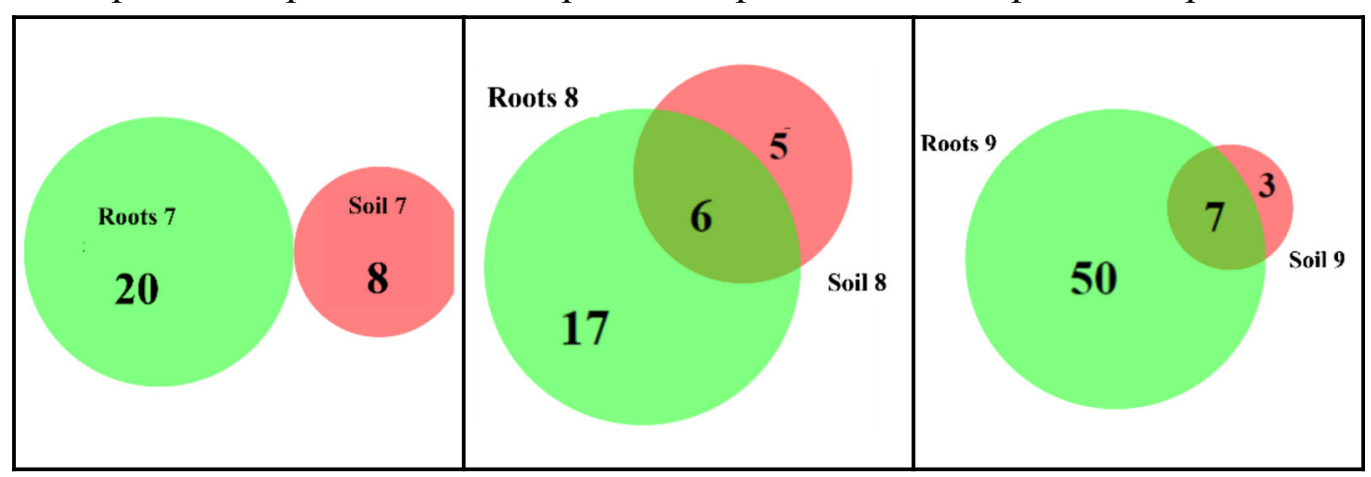

Field 7

Field 8

Field 9

No. plants sampled $=2 \quad$ No. plants sampled $=1 \quad$ No. plants sampled $=5$

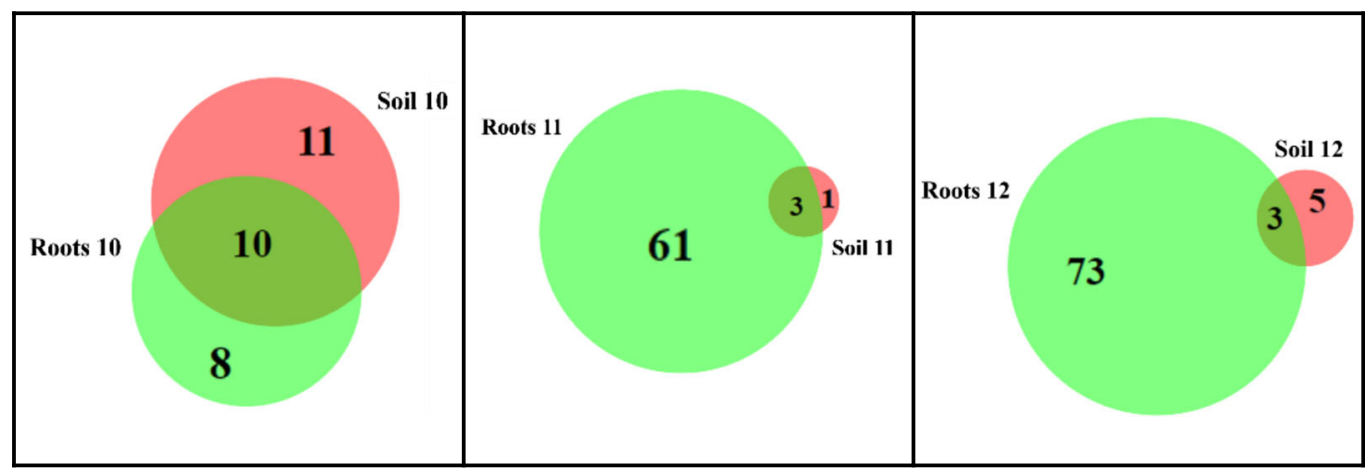

Field 10

No. plants sampled $=1$
Field 11

No. plants sampled $=9$
Field 12

No. plants sampled $=2$ 
Fig. 5 Venn diagrams showing the number of arbuscular mycorrhizal fungal virtual taxa (VT) shared between field soils and the manioc roots collected from the same locations

R package vegan (Oksanen et al. 2011). Sharing of AM fungal taxa between total root and soil samples, and between root and soil samples from the same swidden field was illustrated using Venn diagrams using the Bio-Venn tool of Hulsen et al. (2008).

Neither raw nor log-transformed soil physicochemical variables met the assumptions of analysis of variance, so nonparametric analyses (Kruskal-Wallis tests) were used to evaluate differences in these variables among soil types. Linear regression was used to evaluate the effect of soil variables on the richness of AM fungal communities in soils and manioc roots using the function $I m$ from $\mathrm{R}$.

Non-metric multidimensional scaling analysis (NMDS) was used to visualize the variation of AM fungal communities among soil types and between roots of sweet and bitter manioc landraces (NMDS analysis was performed using the function metaMDS from the $\mathrm{R}$ package vegan (Oksanen et al. 2011). Permutational multivariate analysis of variance (PERMANOVA) was used to test differences among soil types and between sweet and bitter manioc landraces in the composition of AM fungal communities. PERMANOVA was performed using the function adonis from the $\mathrm{R}$ package vegan. To evaluate if individual VT were associated with particular soils or manioc landraces, an indicator species analysis (ISA) (Dufrêne and Legendre 1997) was carried out using the $\mathrm{R}$ function IndVal from R package labdsv. VT with significant ISA values are reported.

All statistical analyses were carried out with $\mathrm{R}$ version 3.5.1. ( $\mathrm{R}$ core team 2016) and with $p \leq 0.05$ as the criterion to consider differences significant.

\section{Results}

\section{Molecular characterization of manioc landraces}

The five manioc landraces (one sweet landrace and four bitter landraces) represented divergent clusters based on their SNP profiles, in accordance with the classification into sweet and bitter landraces made by indigenous farmers in the field (Figure A1 Online Resources).

\section{Molecular diversity of AM fungi in soils and manioc root samples}

A total of 153,927 quality-filtered sequences were recovered from 49 samples, of which 99,865 sequences (64.9\%) were identified as Glomeromycotina. Glomeromycotina sequences belonged to 126 virtual taxa (VT) in 12 genera: Acaulospora (8 VT), Ambispora (2 VT), Archaeospora (6 VT),
Claroideoglomus (3 VT), Dentiscutata (1 VT), Gigaspora (1 VT), Glomus (91 VT), Kuklospora (1 VT), Paraglomus (6 VT), Racocetra (1 VT), Rhizophagus (3 VT), and Scutellospora (3 VT). Nine VT were novel: two Acaulospora, two Archaeospora, four Glomus, and one Scutellospora (Table A3 Online Resource), comprising a total of 1901 sequences (1.9\% of Glomeromycotina sequences). The remaining sequences were mostly Metazoa (52\% of non-glomeromycotinan sequences), Viridiplantae $(15 \%)$, or other fungi (15\%).

All 12 recorded genera of AM fungi were found in soils or roots in Anthrosols. Ambispora was not recorded in Podzols, Gigaspora was not recorded in Fluvisols, Scutellospora was not recorded in Ferralsols, and Racocetra was not recorded in Ferralsols and Fluvisols (Table A3 Online Resource).

Among all Glomeromycotina sequences, 4741 were obtained from soil samples (on average 395 sequences per sample) corresponding to 68 VT (Table A3 Online Resource); and 95,124 sequences were obtained from manioc root samples (on average 2571 sequences per sample) corresponding to 114 VT (Table A3 Online Resource). Rarefaction curves indicated that AM fungal diversity was captured more efficiently from root samples than from soil samples (Fig. 2). Although $91 \%$ of total VT richness was captured from root samples, 12 VT were recovered only from soil samples.

\section{Physicochemical composition of swidden field soils}

Soil physicochemical variables were very variable within each soil type (Table 1). None of the variables tested exhibited significant differences among soil types, although texture (sand $p=0.058$; clay $p=0.088 ; \mathrm{df}=3$, Kruskal-Wallis test) or available $\mathrm{P}$ ( $p=0.062$; $\mathrm{df}=3$, Kruskal-Wallis test) exhibited marginally significant differences.

\section{AM fungal virtual taxa richness in soils and manioc roots}

There were no significant differences in the number of VT among soil samples collected from different soil types $(p=$ $0.42, \mathrm{df}=3$; Kruskal-Wallis test) (Table 2) or among root samples of different manioc landraces $(p=0.33 ; \mathrm{df}=4$; Kruskal-Wallis test) (Table 3). Manioc roots of individual plants were colonized on average by $19 \mathrm{VT}$, independently of the manioc landrace evaluated. Manioc root VT richness was not correlated with differences in soil texture $\left(r^{2}=-\right.$ $0.11 ; \mathrm{df}=9 ; p=0.94$, linear regression $)$ or available $\mathrm{P}\left(r^{2}=\right.$ $-0.09 ; \mathrm{df}=10 ; p=0.82$, linear regression). On the basis of read counts, the most abundant VT collected from soil and root samples were Rhizophagus manihotis (VT90) and Glomus VT126. 


\section{AM fungal community composition in soils and manioc roots}

AM fungal community composition differed significantly among soil types $(p=0.002 ; \mathrm{df}=3$; PERMANOVA) (Fig. 3 ) and marginally significantly among manioc landraces $(p=$ 0.057; $\mathrm{df}=4$; PERMANOVA) (Fig. 4). In addition, indicator species differed among soil types and manioc landraces. Soil samples and manioc roots collected from single fields shared less than $34 \%$ of VT of their AM fungal communities (Fig. 5) and sometimes none (samples from Fields 6 and 7, Fig. 5). Some VT identified as indicator species of Ferralsols were also indicator species in Amarilla manioc roots collected in that soil type (Table 4). However, similar correspondence between indicator VT recorded in soil and manioc root communities did not occur in other soil types. All VT found to be indicator species of particular manioc landraces were morphologically unknown species of Glomus (Table 4).

\section{Discussion}

AM fungal communities in each studied field were different. The AM fungal communities recorded from manioc root samples and soil samples were different, although overall, $44 \%$ of VT were shared between manioc root samples and samples of the soil surrounding them.

Almost twice the number of AM fungal VT were obtained from manioc root samples as from soil samples; however, 12 VT were only recovered from soil samples. Similar results were obtained by Saks et al. (2014), who noted a higher observed VT richness in root samples (76) than in soil samples (37); they also found few (7 out of 76) VT in soil that were not recovered from roots. Our study and the studies by Saks et al. (2014) and Varela-Cervero et al. (2015) reaffirm the importance of using complementary types of samples to estimate total AM fungal richness (and composition), and challenge the view of Chagnon and Bainard (2014) who suggested that only one type of sample is sufficient to characterize an AM fungal community. In this study, VT recovered exclusively from soils were represented by low numbers of reads.

The Amazonian soils and manioc roots studied here harbored diverse AM fungal communities (a total of $126 \mathrm{VT}$ in five manioc landraces and four soil types). The sampled soils differed marginally in texture and in the content of available $\mathrm{P}$, but those differences did not affect AM fungal species richness in manioc roots. Many studies have described a negative impact of high soil $\mathrm{P}$ availability on root AM fungal colonization (Habte and Manjunath 1987; Howeler and Sieverding 1983; Smith et al. 2011). This work indicates that the putatively negative relationship between soil $\mathrm{P}$ availability and AM fungal root colonization is not reflected in AM fungal richness in manioc roots over the observed range in soil $\mathrm{P}$. This was true irrespective of the manioc landrace cultivated as there were no differences in AM fungal richness among the roots of the different manioc landraces studied. Manioc has a strong dependency on the AM association for its nutrition as a consequence of its poorly developed root system, suggesting that this plant species may always attempt to establish a functional AM association, independently of the edaphic or environmental conditions in which it is cultivated. This is broadly supported by the fact that on average 19 VT colonized the
Table 4 Arbuscular mycorrhizal fungal species with significant indicator species value (ISA) for soil types or for manioc landraces

\begin{tabular}{|c|c|c|c|c|c|c|c|}
\hline & Genus & Soil type & ISA value & $p$ value & Manioc landrace & ISA value & $p$ value \\
\hline VT4 & Archaeospora & Anthrosol & 0.45 & 0.044 & & & \\
\hline VT113 & Glomus & Ferralsol & 0.56 & 0.023 & Amarilla & 0.71 & 0.026 \\
\hline VT398 & Glomus & Ferralsol & 0.55 & 0.003 & Amarilla & 0.44 & 0.015 \\
\hline VT126 & Glomus & Ferralsol & 0.49 & 0.028 & & & \\
\hline VT129 & Glomus & Ferralsol & 0.39 & 0.013 & Amarilla & 0.50 & 0.015 \\
\hline LHG107 & Glomus & Ferralsol & 0.31 & 0.043 & & & \\
\hline VT312 & Glomus & Fluvisol & 0.59 & 0.011 & & & \\
\hline VT403 & Glomus & Fluvisol & 0.48 & 0.025 & & & \\
\hline VT92 & Glomus & Fluvisol & 0.46 & 0.019 & & & \\
\hline LHG101 & Glomus & Fluvisol & 0.23 & 0.048 & & & \\
\hline VT89 & Glomus & & & & Borugo & 0.57 & 0.016 \\
\hline VT109 & Glomus & & & & Borugo & 0.50 & 0.008 \\
\hline VT418 & Glomus & & & & Borugo & 0.50 & 0.013 \\
\hline VT410 & Glomus & & & & C. morada & 0.50 & 0.005 \\
\hline MOG76 & Glomus & & & & Yucuna & 0.62 & 0.014 \\
\hline VT364 & Glomus & & & & Yucuna & 0.40 & 0.034 \\
\hline
\end{tabular}


roots of single manioc plants cultivated in swiddens in the Amazon region and a similar number (21 VT) were colonizing manioc roots in a commercial production system in Thailand (Herrmann et al. 2016).

Distinct AM fungal communities associated with the different studied soil types. Glomus and Acaulospora were the most common AM fungal genera in the study area. Both genera have been identified previously as the most common genera in Amazonian soils (Freitas et al. 2014; Peña-Venegas 2010). This is consistent with previous evidence that AM fungi are resilient to swidden agriculture, i.e., swidden agriculture is supposed to retain the AM fungal community structure of previous primary and secondary forest (Chaudhary et al. 2018; García de León et al. 2018). Although all 12 AM genera were recorded in Anthrosols, the genus Archaeospora was an indicator genus of this soil. Martínez-García et al. (2015) noted a particular abundance of Archaeosporaceae in young vegetation stages with high content of total (and likely also of available) P. It is likely that members of this family are favored by the high $\mathrm{P}$ of Anthrosols. This result provides evidence of how human modification of Amazonian soils into Anthrosols (Glaser and Birk 2012) may have affected soil AM fungal communities.

In individual fields, less than $34 \%$ of the AM fungal community colonizing manioc roots was shared by the soils in which plants were growing (Fig. 5). In previous spore-based studies, Rhizophagus irregularis (Ceballos et al. 2013), Paraglomus occultum (Dodd et al. 1990), Acaulospora colombiana, and Ambispora appendiculata (Séry et al. 2016) were reported as AM fungal species with affinity for manioc. Among them, $R$. irregularis and P. occultum were present in our study area, but none of the four species named were among the most important symbionts of manioc in our study. Manioc roots of single plants were colonized naturally by around 19 VT, most representing were unknown species that could only be identified using molecular approaches. Our results indicate that surveying AM fungal spores in soil near manioc roots may not provide an accurate indication of which AM fungal species are abundant colonizers of manioc.

The most frequent AM fungal species colonizing manioc roots were Rhizophagus manihotis and Glomus VT126, which were also abundant in soils; however, all the AM fungi identified as indicator species of particular manioc landraces were morphologically unknown Glomus. Three VT identified as indicator species of Ferralsols were also identified as indicator species of the Amarilla manioc landrace. The Amarilla manioc landrace is a common yellowroot, bitter landrace used to prepare farinha and has been commonly associated with acid, low-fertility soils such as Ferralsols (Arroyo-Kalin 2010; Wilson and Dufour 2002), indicating that parallel adaptation to Ferralsols of this manioc landrace and certain VT could have occurred. However, such potential convergence was not observed for any other landrace or soil evaluated.

Glomus VT403, which was indicated in an earlier molecular study to have a strong affinity for manioc (Herrmann et al. 2016), was also recorded in this study as an indicator species of Fluvisols but not as an indicator species of any specific manioc landrace evaluated. Furthermore, five AM fungal species identified as indicator species of manioc in the work of Herrmann et al. (2016) that were also present in our study area (VT28, VT403, VT312, VT248, and VT108) were not indicator species for any of the manioc landraces evaluated. Rhizophagus manihotis (VT90) which was identified as a common species colonizing manioc roots in this study was identified by Herrmann et al. (2016) as an indicator species of rubber tree and not of manioc.

These results indicate that the performance of different AM fungal taxa might be context-specific and their response to environmental conditions (Heyde et al. 2017) or host plants (even different varieties from the same species) might not be predictable at large scales. This context dependency implies potential limitations for the selection of a particular AM fungal inoculant for manioc.

\section{Conclusions}

Manioc naturally established AM associations with a high number of AM fungi irrespective of the soil conditions or the manioc landrace evaluated. Rhizophagus manihotis and Glomus VT126 were the most frequent AM fungal species present in manioc roots and surrounding soils. Important AM fungal indicator species for particular manioc landraces were Glomus taxa known only from analysis of environmental DNA. AM fungi previously reported as important AM symbionts for manioc occurred in this study area, but were only minor and infrequent manioc root colonizers. These results suggest some selectivity in manioc-AM fungal associations and potentially indicate that the most beneficial symbionts for individual crop species may differ from place to place.

Acknowledgments We express our gratitude to Luis Augusto Becerra Lopez-Lavalle from CIAT, Colombia, for his help with the molecular analysis of manioc root samples; to Dominique Dufour from CIRAD, France, for his help regarding manioc toxicity; to Dr. David Janos for his dedicated review and recommendations to improve this manuscript; and to the many indigenous women who provided invaluable help identifying manioc landraces and collecting soil and root samples for this study.

Funding information We thank the Terra Preta Programme funded by the Interdisciplinary Research and Education Fund (INREF) of Wageningen University (The Netherlands) and the Instituto Amazónico de Investigaciones Científicas Sinchi (Colombia) for funding this research. MÖ, MV, TJ, and JD were funded by the Estonian Research Council 
(grant IUT20-28) and the European Regional Development Fund (Centre of Excellence EcolChange).

Open Access This article is distributed under the terms of the Creative Commons Attribution 4.0 International License (http:// creativecommons.org/licenses/by/4.0/), which permits unrestricted use, distribution, and reproduction in any medium, provided you give appropriate credit to the original author(s) and the source, provide a link to the Creative Commons license, and indicate if changes were made.

\section{References}

Altschul SF, Gish W, Miller W, Myers EW, Lipman DJ (1990) Basic local alignment search tool. J Mol Biol 215:403-410

Anderson IC, Cairney JWG (2004) Diversity and ecology of soil fungal communities: increased understanding through the application of molecular techniques. Environ Microbiol 6:769-779

Aristizábal J, Sánchez T, Lorío DM (2007) Guía técnica para producción y análisis de almidón de yuca. FAO 163, Roma

Arroyo-Kalin M (2010) The Amazonian formative: crop domestication and anthropogenic soils. Diversity 2:473-504

Bik HM, Porazinska DL, Creer S, Caporaso JG, Knight R, Thomas WK (2012) Sequencing our way towards understanding global eukariotic biodiversity. Trends Ecol Evol 27:233-243

Burns AE, Gleadow RM, Cliff J, Zacarias AM, Cavagnaro TR (2010) Cassava: the drought, war and famine crop in a changing world. Sustainability 2:3572-3607

Cadavid LF, El-Sharkawy MA, Acosta A, Sanchez T (1998) Long-term effects of mulch, fertilization and tillage on cassava grown in sandy soils in northern Colombia. Field Crop Res 57:45-56

Camacho C, Coulouris G, Avagyan V, Ma N, Papadopoulos J, Bealer K, Madden TL (2009) BLAST+: architecture and applications. BMC Bioinformatics 10:421

Cardoso IM, Kuyper TW (2006) Mycorrhizas and tropical soil fertility. Agric Ecosyst Environ 116:72-84

Cavechia LA, Cantor M, Begossi A, Peroni N (2014) Resource-use patterns in swidden farming communities: implications for the resilience of cassava diversity. Hum Ecol 42:605-616

Ceballos I, Ruiz M, Fernández C, Peña R, Rodríguez A, Sanders IR (2013) The in vitro mass-produced model mycorrhizal fungus, Rhizophagus irregularis, significantly increases yields of the globally important food security crop cassava. PLoS One 8:e70633

CIAT (1984) Morphology of the cassava plant: study guide. CIAT, Cali

Chagnon PL, Bainard LD (2014) Is root DNA a reliable proxy to assess arbuscular mycorrhizal community structure? Can J Microbiol 60: $619-624$

Chaudhary VB, Cuenca G, Johnson NC (2018) Tropical-temperate comparison of landscape-scale arbuscular mycorrhizal fungal species distributions. Divers Distrib 24:116-128

Davison J, Öpik M, Zobel M, Vassar M, Metsis M, Moora M (2012) Communities of arbuscular mycorrhizal fungi detected in forest soil are spatially heterogeneous but do not vary throughout the growing season. PLoS One 7:e41938

Delaquis E, Haan S, Wyckhuys KAG (2018) On-farm diversity offsets environmental pressures in tropical agroecosystems: a synthetic review for cassava-based systems. Agric Ecosyst Environ 251:226-235

Dodd JC, Arias I, Koomen I, Hayman DS (1990) The management of populations of vesicular-arbuscular mycorrhizal fungi in acidinfertile soils of a savanna ecosystem. I. The effect of pre-cropping and inoculation with VAM-fungi on plant growth and nutrition in the field. Plant Soil 122:229-240

Dufrêne M, Legendre P (1997) Species assemblages and indicator species: the need for a flexible asymmetrical approach. Ecol Monogr $67: 345-366$
Duivenvoorden JF, Lips JM (1993) Landscape ecology of the Middle Caquetá basin. In: Studies in the Colombian Amazonia, vol IIIA. Tropenbos Colombia, Bogotá

Edgar RC, Haas BJ, Clemente JC, Quince C, Knight R (2011) UCHRIME improves sensitivity and speed of chimera detection. Bioinformatics 27:2194-2200

El-Sharkawy MA (2004) Cassava biology and physiology. Plant Mol Biol 56:481-501

El-Sharkawy MA, Tafour SM (2010) Comparative photosynthesis, growth, productivity, and nutrient use efficiency among tall- and short-stemmed rain-fed cassava cultivars. Photosynthetica 48(2):173-188

Emperaire L, Peroni N (2007) Traditional management of agrobiodiversity in Brazil: a case study of manioc. Hum Ecol 35:761-768

FAO (2000) The world cassava economy: facts, trends and outlooks. Food and Agriculture Organization of the United Nations and International Fund for Agricultural Development. FAO Italy, Rome, pp 1-59

Fagbola O, Osonubi O, Mulongoy K (1998) Contribution of arbuscular mycorrhizal (AM) fungi and hedgerow trees to the yield and nutrient uptake of cassava in an alley-cropping system. J Agric Sci 131:79-85

Freitas RO, Buscardo E, Nagy L, Maciel ABS, Carrenho R, Luizão RCC (2014) Arbuscular mycorrhizal fungal communities along a pedohydrological gradient in a Central Amazonian terra firme forest. Mycorrhiza 24:21-32

Fresco LO (1986) Cassava in shifting cultivation: a systems approach to agricultural technology development in Africa. Royal Tropical Institute, Amsterdam

García de León D, Neuenkampa L, Moora M, Öpik M, Davison J, PenaVenegas CP, Vasar M, Jairus T, Zobel Martin Z (2018) Arbuscular mycorrhizal fungal communities in tropical rain forests are resilient to slash-and-burn agriculture. J Trop Ecol 34:186-199

Gazol A, Zobel M, Cantero JJ, Davison J, Esler KJ, Jairus T, Öpik M, Vasar M, Moora M (2016) Impact of alien pines on local arbuscular mycorrhizal fungal communities - evidence from two continents. FEMS Microbiol Ecol 92:fiw073

Glaser B, Birk JJ (2012) State of the scientific knowledge on properties and genesis of Anthropogenic Dark Earths in Central Amazonia (terra preta de Índio). Geochim Cosmochim Acta 82:39-51

Habte M, Byappanahalli MN (1994) Dependency of cassava (Manihot esculanta Crantz) on vesicular-arbuscular mycorrhizal fungi. Mycorrhiza 4:241-245

Habte M, Manjunath A (1987) Soil solution phosphorus status and mycorrhizal dependency in Leucaena leucocephala. Appl Environ Microbiol 53:797-801

Herrmann L, Lesueur D, Bräu L, Davison J, Jairus T, Robain H, Robin A, Vasar M, Wiriyakitnateekul W, Öpik M (2016) Diversity of rootassociated arbuscular mycorrhizal fungal communities in a rubber tree plantation chronosequence in Northeast Thailand. Mycorrhiza 26:863-877

Heyde M, Ohsowski B, Abbott LK, Hart M (2017) Arbuscular mycorrhizal fungus responses to disturbance are context-dependent. Mycorrhiza 27:431-440

Howeler RH, Sieverding E (1983) Potentials and limitations of mycorrhizal inoculation illustrated by experiments with field-grown cassava. Plant Soil 75:245-261

Hulsen T, Vlieg JD, Alkema W (2008) BioVenn - a web application for the comparison and visualization of biological lists using areaproportional Venn diagrams. BMC Genomics 9:488

IGAC (1979) La Amazonia Colombiana y sus recursos Proyecto radargramético del Amazonas PRORADAM. IGAC, Bogotá

IGAC (2006) Métodos analíticos del laboratorio de suelos 23. Instituto Geográfico Agustín Codazzi, Bogotá

Jakobsson M, Rosenberg NA (2007) CLUMPP: a cluster matching and permutation program for dealing with label switching and multimodality in analysis of population structure. Bioinformatics 23:1801-1806 
Kawuki RS, Herselman L, Labuschagne MT, Nzuki I, Ralimanana I, Bidiaka M, Kanyange MC, Gashaka G, Masumba E, Mkamilo G, Gethi J, Wanjala B, Zacarias A, Madabula F, Ferguson ME (2013) Genetic diversity of cassava (Manihot esculenta Crantz) landraces and cultivars from southern, eastern and central Africa. Plant Genet Resourc 11:170-181

Lee J, Lee S, Young JPW (2008) Improved PCR primers for the detection and identification of arbuscular mycorrhizal fungi. FEMS Microbiol Ecol 65:339-349

Leihner D (2002) Agronomy and cropping systems. In: Hillocks RJ, Thresh JM, Bellotti A (eds) Cassava: biology, production and utilization. CABI publishing, London, pp 91-113

Li J, Deng T, Chu X, Yang R, Jiang J, Shen G, Yu R (2010) Rolling circle amplification combined with gold nanoparticle aggregates for highly sensitive identification of single-nucleotide polymorphisms. Anal Chem 82:2811-2816

Martínez-García LB, Richardson SJ, Tylianakis JM, Peltzer DA, Dickie IA (2015) Host identity is a dominant driver of mycorrhizal fungal community composition during ecosystem development. New Phytol 205:1565-1576

McKey D, Beckerman S (1993) Chemical ecology, plant evolution and traditional manioc cultivation systems. In: Hladik CM, Hladik A, Linares OF, Pagezy H, Semple A, Hadley M (eds) Tropical forests, people and food. Biocultural Interactions and Applications to Development Chapter 8. Parthenon (Carnforth) and UNESCO (Paris), New York, pp 83-112

McKey D, Cavagnaro TR, Cliff J, Gleadow R (2010) Chemical ecology in coupled human and natural systems: people, manioc, multitrophic interactions and global change. Chemoecology 20:109-133

Milne I, Wright F, Rowe G, Marshal DF, Husmeier D, McGuire G (2004) TOPALi: software for automatic identification of recombinant sequences within DNA multiple alignments. Bioinformatics 20:1806-1807

Nakabonge G, Samukoya C, Baguma Y (2017) Local varieties of cassava: conservation, cultivation and use in Uganda. Environ Dev Sustain 20(6):2427-2445

Oksanen J, Blanchet FG, Kindt, R, Legendre P, O'Hara RB, Simpson G, Solymos P, Stevens MHH, Wagner H (2011) Vegan: community ecology package, ver. $2.02 \mathrm{http}: / /$ veganr-forger-project.org/

Omorusi VI, Ayanru DKG (2011) Effect of NPK fertilizer on diseases, pests and mycorrhizal symbiosis in cassava. Int J Agric Biol 13:391-395

Öpik M, Davison J, Moora M, Zobel M (2014) DNA-based detection and identification of Glomeromycota: the virtual taxonomy of environmental sequences. Botany 92:135-147

Öpik M, Metsis M, Daniell TJ, Zobel M, Moora M (2009) Large-scale parallel 454 sequencing reveals host ecological group specificity of arbuscular mycorrhizal fungi in a Boreonemoral forest. New Phytol 184:424-437

Öpik M, Moora M, Liira J, Zobel M (2006) Composition of rootcolonizing arbuscular mycorrhizal fungal communities in different ecosystems around the globe. J Ecol 94:778-790

Öpik M, Zobel M, Cantero JJ, Davison J, Facelli JM, Hiiesalu I, Jairus T, Kalwij JM, Koorem K, Leal ME, Liira J, Metsis M, Neshataeva V, Paal J, Phosri C, Põlme S, Reier Ü, Saks Ü, Schimann H, Thiéry O, Vasar M, Moora M (2013) Global sampling of plant roots expands the described molecular diversity of arbuscular mycorrhizal fungi. Mycorrhiza 23:411-430

Parameswaran P, Jalili R, Tao L, Shokralla S, Gharizadeh B, Ronaghi M, Fire AZ (2007) A pyrosequencing-tailored nucleotide barcode design unveils opportunities for large-scale sample multiplexing. Nucleic Acids Res 35:e130

Peña-Venegas CP (2010) Arbuscular mycorrhizal fungi in the Amazon region. In: Pagano M (ed) Mycorrhiza: occurrence in natural and restored environments. Nova Publishers, New York, pp 75-86

Peña-Venegas CP, Stomph TJ, Verschoor G, Lopez-Lavalle LAB, Struik PC (2014) Differences in manioc diversity among five ethnic groups of the Colombian Amazon. Diversity 6:792-826
Pritchard JK, Stephens M, Donnelly P (2000) Inference of population structure using multilocus genotype data. Genetics 155:945-959

R Core Team (2016). R: A language and environment for statistical computing. R version 3.5.1. R Foundation for Statistical Computing, Vienna, Austria. URL http://www.R-project.org/

Saks Ü, Davison J, Öpik M, Vassar M, Moora M, Zobel M (2014) Rootcolonizing and soil-borne communities of arbuscular mycorrhizal fungi in a temperate forest understorey. Botany 92:277-285

Séry DJ, Kouadjo ZGC, Voko BR, Zézé A (2016) Selecting native arbuscular mycorrhizal fungi to promote cassava growth and increase yield under field conditions. Front Microbiol 7:1-13

Sieverding E (1990) Should VAM inocula contain single or several fungal species? Agric Ecosyst Environ 29:391-396

Sieverding E, Howeler RH (1985) Influence of species of VA mycorrhizal fungi on cassava yield response to phosphorus fertilization. Plant Soil 88:213-221

Sieverding E, Toro ST (1990) Effect of mixing VAM inoculum with fertilizers on cassava nutrition and VAM fungal association. Agric Ecosyst Environ 29:397-401

Simon L, Lalonde M, Bruns TD (1992) Specific amplification of 18S fungal ribosomal genes from VA endomycorrhizal fungi colonizing roots. Appl Environ Microbiol 58:291-295

Smith SE, Jacobsen I, Gronlund M, Smith FA (2011) Roles of arbuscular mycorrhizas in plant phosphorus nutrition: interactions between pathways of phosphorus uptake in arbuscular mycorrhizal roots have important implications for understanding and manipulating plant phosphorus adquisition. Plant Physiol 156:1050-1057

Spatafora JW, Chang Y, Benny GL, Lazarus K, Smith ME, Berbee ML, Bonito G, Corradi N, Grigoriev I, Gryganskyi A, James TY, O'Donnell K, Roberson RW, Taylor TN, Uehling J, Vilgalys R, White MM, Stajich JE (2016) A phylum-level phylogenetic classification of zygomycete fungi based on genome-scale data. Mycologia 108:1028-1046

Spurgeon SL, Jones RC, Ramakrishnan R (2008) High throughput gene expression measurement with real time PCR in a microfluidic dynamic array. PLoS One 3:e1662

Straker CJ, Hilditch AJ, Rey MEC (2010) Arbuscular mycorrhizal fungi associated with cassava (Manihot esculenta Crantz) in South Africa. S Afr J Bot 76:102-111

Varela-Cervero S, Vassar M, Davison J, Bares JM, Öpik M, AzcónAguilar C (2015) The composition of arbuscular mycorrhizal fungal communities differs among the roots, spores and extraradical mycelia associated with five Mediterranean plant species. Environ Microbiol 17:2882-2895

Voko DRB, Nandjui J, Séry JD, Fotso B, Amoa JA, Kouadio MA, Coulibary S, Niamke S, Zézé A (2013) Abundance and diversity of arbuscular mycorrhizal fungal (AMF) communities associated with cassava (Manihot esculenta Crantz) rhizosphere in Abengourou, East Côte d'Ivoire. J Ecol Nat Environ 5(11):360-370

Waterhouse AM, Procter JB, Martin DMA, Clamp M, Barton GJ (2009) Jalview Version 2 - a multiple sequence alignment editor and analysis workbench. Bioinformatics 25:1189-1191

Wilson WM, Dufour DL (2002) Why "Bitter" cassava? Productivity of "Bitter" and "Sweet" cassava in a Tukanoan Indian Settlement in the Northwest Amazon. Econ Bot 56:49-57

WRB (2016) IUSS Working Group WRB, 2015. Base referencial mundial del recurso suelo 2014, Actualización 2015. Sistema internacional de clasificación de suelos para la nomenclatura de suelos y la creación de leyendas de mapas de suelos. Informes sobre recursos mundiales de suelos 106. FAO, Roma: 90-121

Publisher's note Springer Nature remains neutral with regard to jurisdictional claims in published maps and institutional affiliations. 